\title{
"Medium-Scale" Forestland Grabbing in the Southwestern Highlands of Ethiopia: Impacts on Local Livelihoods and Forest Conservation
}

\author{
Tola Gemechu Ango
}

Department of Human Geography, Stockholm University, SE-106 91 Stockholm, Sweden; tola.gemechu@humangeo.su.se

Received: 11 January 2018; Accepted: 11 February 2018; Published: 14 February 2018

\begin{abstract}
Tropical forest provides a crucial portion of sustenance in many rural communities, although it is increasingly under pressure from appropriations of various scales. This study investigated the impacts of medium-scale forestland grabbing on local livelihoods and forest conservation in the southwestern highlands of Ethiopia. Data were generated through interviews, discussions and document review. The results indicate that state transfer of part of the forestland since the late 1990s to investors for coffee production created in situ displacement- a situation where farmers remained in place but had fully or partially lost access to forest- that disrupted farmers' livelihoods and caused conflicts between them and the investors. Court cases about the appropriated land and related imprisonment, inflicted financial and opportunity costs on farmers. Farmers considered the livelihood opportunities created by the companies insufficient to compensate for loss of forest access. Companies' technology transfers to farmers and contributions to foreign currency earnings from coffee exports have not yet materialized. Forest conservation efforts have been negatively affected by deforestation caused by conversion to coffee plantations and by farmers' efforts to secure rights to forestland by more intensive use. The medium-scale forestland grabbing has been detrimental to farmers' livelihoods and forest conservation in a way that recalls criticism of large- and mega-scale land grabbing since 2007-2008. The overall failure to achieve the objectives of transferring forestland to investors highlights a critical need to shift institutional supports to smallholders' informal forest access and management practices for better development and conservation outcomes.
\end{abstract}

Keywords: appropriation; coffee investment; deforestation; development; Ethiopia; forest access; medium-scale forestland grabbing; in situ displacement; Oromia

\section{Introduction}

Tropical forest is an important resource for local livelihoods and food security in many rural communities and is also among the biological resources prioritized for conservation [1,2]. This forest is increasingly under pressure from appropriations of various scales: small- $(<100 \mathrm{ha})$, medium(100-1000 ha), large- (1001-10,000 ha) and mega- (>10,000 ha) scale land grabbing ${ }^{1}[3,5-7]$. This study investigates the impacts of medium-scale forestland transfers for coffee production on local livelihoods and forest conservation in southwestern Ethiopia and their implications for strategies, such as Ethiopia's 2011 climate-resilient green economic development strategy [8], to create conservation and development synergy.

1 There are no universal definitions of small-, medium-, large- and mega- scale land appropriations. Here, this classification is preferred because to some extent it highlights the trend in land appropriations since the mid-1990s that culminated in mega-scale land grabbing around 2007-2008, at least in Ethiopia (cf., [3,4]). 
There has been substantial research into and growing understanding of the processes, drivers, magnitude and social-ecological impacts of the large- and mega-scale global land grabbing that started in 2007-2008 in Ethiopia and elsewhere in the global south (e.g., [5,7,9-15]). Despite the potentials of agricultural investments in the appropriated lands to promote rural development (e.g., [16]), the expectation that such investments could be engine of economic development and food security for the countries in the global south has not yet materialized $[3,10,17]$. Instead, global land grabbing has increasingly undermined local livelihoods and development, since it has involved appropriations of agricultural and forest lands, which have been vital resources for local farmers and pastoralists, and displacements [14,18-20] as well as aggravated forest clearance and biodiversity loss [5].

Ethiopia is one of the countries that have recently transferred vast tracts of land, largely to foreign investors [21], for export, biofuel and industrial crop production [3]. Although the exact extent of such land transfers in Ethiopia is as yet unknown, an estimated 3-3.5 million ha have been transferred since the mid-1990s [3]. The large-and mega-scale land dispossessions in Ethiopia are "spatially differentiated," with huge tracts of land in peripheral lowland parts of the country having been appropriated $[22,23]$. Such spatially differentiated appropriations were based on the claim that the peripheral lowlands are uninhabited, unused, or underutilized lands that must be made more productive to contribute to national development $[17,19,24]$.

Apart from the recent global land grabbing, in Ethiopia many small- and medium-scale land appropriations for commercial agriculture and industrial and urban development have also been effected since the mid-1990s [22,25]. The state has transferred small- and medium-scale land parcels to mainly domestic investors [3]. However, compared with large-and mega-scale land grabs, little is known about the social, economic and environmental impacts of the small- and medium-scale appropriations in Ethiopia (exceptions, $[18,25,26]$ ) and elsewhere $[27,28]$. Most of these studies focused on agricultural land appropriations; and none of these and no other known studies have sufficiently engaged with smaller size forestland appropriations. In contrast to the large- and mega-scale appropriations of sparsely populated lowlands, highlands (i.e., areas over 1500 meters above sea level, masl), for instance, in central and southwest Ethiopia, have been common sites of many smalland medium-scale land grabs over the past two decades $[18,25]$. Given that the highlands support at least $80 \%$ of Ethiopia's 92 million inhabitants as of 2016, most of whom are smallholding farmers [29,30], land dispossessions in these areas can be expected to have far-reaching negative implications for local livelihoods and development prospects [25].

The present study examined medium-scale state transfers of forestland to investors for coffee production in the southwestern Ethiopian highlands since the late 1990s. Understanding the extent and impacts of the forestland appropriations in the region is important since the southwest forest is a major portion of Ethiopia's remaining forest. Most importantly, this forest shelters the gene pools of many important crops, including coffee (Coffea arabica) and false cardamom (Aframomum corrorima) [31], in addition to supporting local forest-based livelihoods, for example, through shade coffee (i.e., coffee grown under shade trees) and honey production [32,33]. Coffee is a dominant export commodity accounting for over $25 \%$ of Ethiopia's total foreign currency earnings and the coffee production sector supports the livelihoods of over 15 million people [34]. Forest coffee ecosystems, i.e., "forest coffee" and "semi-managed forest coffee" production by smallholders, mostly in south and southwest and to some extent in southeast Ethiopia [35] account for about 45 percent of the country's total coffee production ${ }^{2}$. Smallholders' coffee production involves the use of local knowledge and techniques, which are often relatively biodiversity friendly (cf., $[35,37])$. Accordingly, coffee production in the forest coffee ecosystems, as recently demonstrated, has slowed deforestation in southwest Ethiopia [38]. The economic contribution of coffee seems to be a factor motivating the government to further expand

2 Garden coffee system- production of coffee from trees planted by smallholders in and around their gardens- and commercial plantation coffee account for about $50 \%$ and $5 \%$ of the total coffee production, respectively [36]. 
coffee production through promoting private-sector involvement in coffee investment [34]. Plans for more land appropriations, including investments in forest coffee ecosystems [34,39], may, however, contradict the national goal of reducing deforestation, identified as a key contributor to inclusive and climate-resilient green economic development in Ethiopia [8].

Within southwestern highlands this study was conducted in the Gera district, where in the late 1990s and 2000s over 1500 ha or c. $1.8 \%$ of the forestland (author's estimation) was transferred to private companies. The impacts of this forestland transfer on local livelihoods were investigated in terms of the benefits and alternative livelihoods (e.g., jobs and technology transfers) that the private companies generated for the local community. Intensive forest use and conversions for coffee production during and after the transfer of forestland to private companies were explored as emerging forest conservation challenges.

\section{Appropriation and In Situ Displacement: A Conceptual Framework}

Recent large-and mega-scale land and resource appropriations or 'grabs,' in the global south can be seen as continuing historical dispossessions that include colonization and enclosures made for 'development and conservation purposes' [40,41]. Due to weak legal recognition of customary rights to commons, forest and pasturelands have historically been and still are easy prey to dispossessions justified by development and conservation narratives [6,7,42-44]. The neoliberal-oriented policy of privatizing commons is one tool for dispossession and capital accumulation in contemporary capitalism $[42,45]^{3}$. By using coercive power to appropriate and allocate land and resources for 'development' or 'conservation,' state politics and elites have been playing a key role in driving processes of dispossession [47,48]. Overall, global processes coupled with domestic politics and economic and historical factors shape the nature and effects of land appropriations $[17,23,41,49]$.

Displacement-physical relocation of former users (farmers and pastoralists) from the appropriated lands and loss of the entire livelihood resource base are richly documented and well-understood effects of land and resources appropriations including the recent large- and mega-scale land and resource grabbing (e.g., [12,19]). However, there is growing understanding that not all appropriations lead to the physical relocation of former users; rather, some appropriations create in situ displacement that encompasses a situation whereby people remain in place but face new restrictions on using the resources they formerly accessed $[13,50]$. Studies from Africa and Asia have documented, albeit implicitly, in situ displacements related to contemporary land appropriations. Examples of such displacements include: large- and mega-scale land appropriations for commercial agriculture in the peripheral lowlands of Ethiopia, which have undermined the livelihoods of pastoralists by limiting the sizes of resources, for instance, land they can access [18,23]; appropriations of communal grazing and farmlands that have weakened the income and food security of smallholder farmers in Bako in Ethiopia [14]; 'multi-stage' dispossessions over longer periods that have had major cumulative effects on small producers in Bangladesh [51]; and out-grower schemes for biofuel and sugar cane in Ethiopia [18,52] and South Africa [53] that have exposed farmers' means of subsistence to new risks, including market vulnerability.

Forestland appropriation and its effects in the Southwest highlands of Ethiopia are conceptualized as in situ displacement, whereby farmers who had lost access to forestland have retained their annual cropland and homesteads and they have thus been able to remain in the area. This appropriation, as will

3 Marx ([46], p. 1021) asserts that enclosures of the commons separated "the producer from the means of production," transforming the producer to a proletariat that created the 'original or primitive accumulation of capital' - a precondition for capitalism. Harvey [45] has redefined Marx's primitive accumulation as ongoing processes of 'accumulation by dispossessions' of various public assets and common resources. Over-accumulation of capital, which is a basic problem of capitalism, "is a condition where surpluses of capital [ ... ] lie idle with no profitable outlets in sight. [ ... ] What accumulation by dispossession does is to release a set of assets (including labour power) at very low (and in some instances zero) cost. Over-accumulated capital can seize hold of such assets and immediately turn them to profitable use" ([45], p. 149). 
be highlighted in the later sections of the current study, has effectively alienated farmers from forestland transferred to private companies and the income from forest coffee production and other forest ecosystem services that are critical to sustain the local livelihoods. Low-paying temporary jobs created by the private companies and the absence of technology transfers from the companies to the farmers that imply exploitation and local livelihood deterioration further illustrate other important dimensions of the in situ displacement in the medium-scale forestland appropriation. This conceptualization provides a unique opportunity to understand how appropriations of a small but critical part of the land and resources used by local farmers can have far-reaching implications for local livelihoods and forest conservations.

\section{Context, Research Setting and Methods}

\subsection{Forestland Appropriations, Ownership and Management Issues in Ethiopia: A Brief Context}

Before the expansion of the Abyssinian Empire into the southern part of present-day Ethiopia in the late nineteenth century [54], the forestland was mainly owned by local communities [55]. The imperial government, church and nobility took over forest ownership until the mid-1970s [56]. Since the mid-1970s, the state has become the formal owner of most forestland [56,57], although communities in many places have retained access ${ }^{4}$, i.e., customary or de facto rights to such forests $[59,60]$ to obtain important forest ecosystem services to sustain their livelihoods [32,61].

The southwest forest has also been a frontier for agriculture expansion [62,63]. Before the mid-1970s, coffee and cereals (e.g., maize) were commonly produced, often by clearing forest [63,64], while during the socialist era, 1974-1991, state coffee farms and agricultural producers' cooperatives were established and expanded into the southwest forest [63]. More recently, forestland has been transferred to a large number of investors for coffee production. For example, about thirty small enterprises were licensed to establish coffee plantations by the early 2000s in the Kafa zone of the Southern Nations, Nationalities and Peoples' Region [65]. Between the mid- and late 2000s alone, 49 investors also started coffee developments on about 8900 ha of forestland formally controlled by the state-owned Oromia Forest and Wildlife Enterprise-Jimma Branch Office (OFWE-JBO) in the Jimma zone of the Oromia Region (Letter from OFWE-JBO to OFWE, dated 1 June 2011).

State concerns about forest conservation emerged in 1965 when the Imperial government launched a forestry proclamation [62]. Until recently, state forest management had applied a top-down approach and failed to mitigate deforestation and forest biodiversity loss [56]. A participatory forest management (PFM) project was started in the late 1990s and since then similar projects have been implemented in various parts of the country, including in the study area [66,67]. The PFM projects have achieved observed success in terms of improved forest condition and local livelihoods [66,68,69], although the sustainability of these projects has been questioned in relation to the lack of effective institutional support after donors exit and in terms of the extent to which decision-making powers devolved to and forest benefits were shared with the local communities $[67,68]$.

On the other hand, state interest in the forest not only for biodiversity conservation but also for poverty reduction, food security, climate change mitigation and national economic development is increasing in Ethiopia [8,70], as in many countries in the global south [71]. A key indicator of such growing interest is Ethiopia's 2011 climate-resilient green economy strategy that considered forest conservation and rehabilitation as one of its key pillars to ensure green and inclusive economic development to raise the country to a middle-income status by 2025 [8]. As part of implementing this strategy, the regime has finalized preparations to implement the Reducing Emissions from Deforestation and Forest Degradation Plus (REDD+) program [72]. In nutshell, forest ownership, use and conservation in Ethiopia have been associated with contestations, claims and counterclaims

4 Access refers to "the ability [emphasis in the original] to derive benefits from" resources ([58], p. 153). 
mainly between local farmers and state actors with implications for local livelihoods, development and forest biodiversity conservation.

\subsection{Description of the Study Area and Coffee Investment}

Gera district is located in the Oromia Region of Ethiopia (Figure 1). The district covers 145,413 ha, of which $96 \%$ are highlands [73]. In 2016, the district had over 141,000 inhabitants with a crude population density of 97 persons per $100 \mathrm{ha}^{2}$ [29]. Ninety-five percent of the inhabitants of the district are rural residents [29]. Eighty-six percent of the inhabitants belong to the Oromo ethnic group [74]. Cultivation of cereals, pulses, tubers and coffee as well as livestock rearing and honey production are widely practiced. In Gera and nearby areas, about $49 \%$ of household income derives from forest-based production activities, namely, coffee, honey and spice production [32].

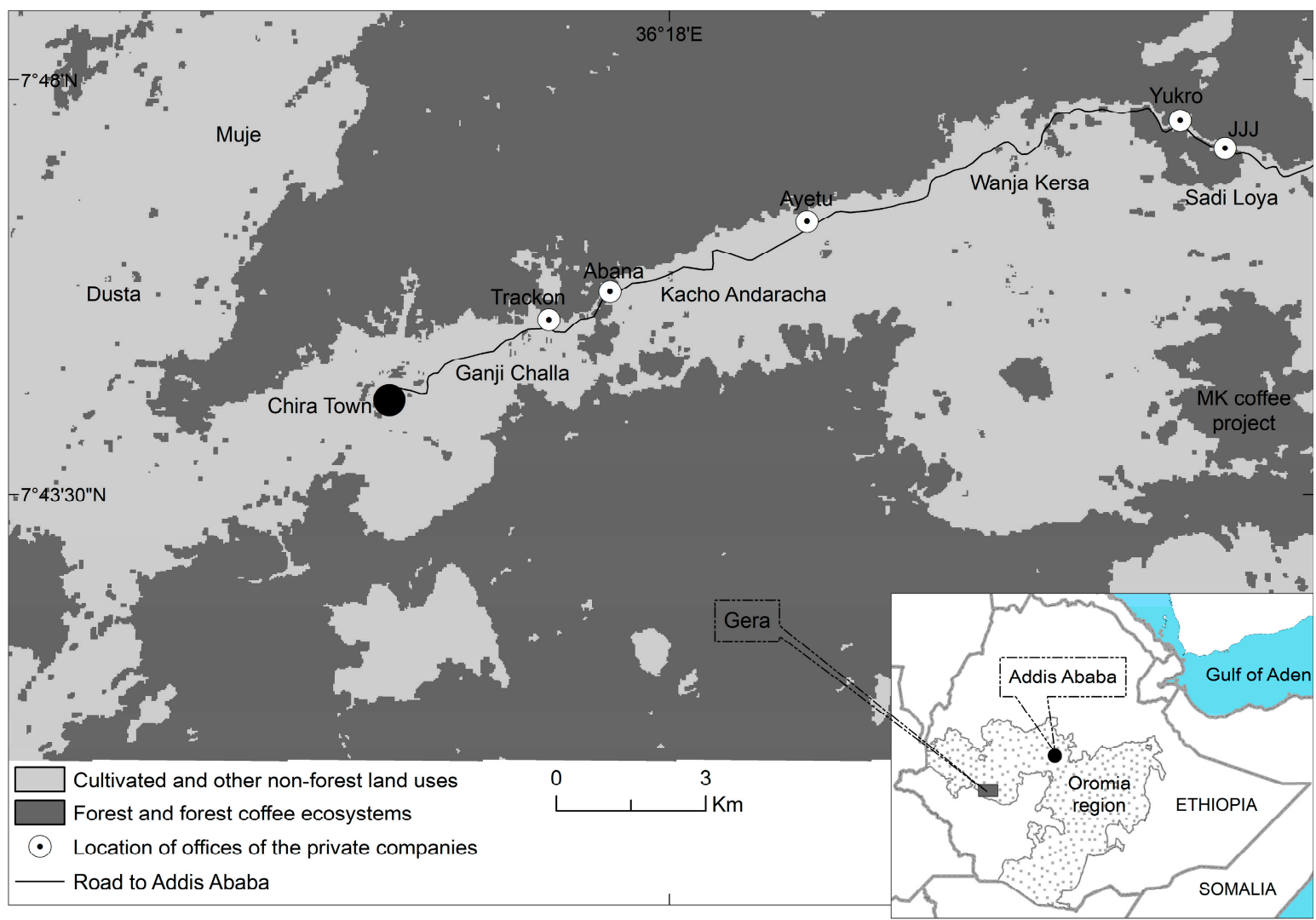

Figure 1. Location of the study area and the private companies engaged in coffee production. The land transferred to the companies is located adjacent to their respective offices indicated on the map. The background land-cover map was produced from a free Landsat image from 5 November 2010 (http://glovis.usgs.gov).

Forest and forest coffee ecosystems cover nearly $60 \%$ of the total area of Gera [75]. The Japan International Cooperation Agency (JICA) together with OFWE initiated a PFM scheme in 2003 to improve the management of forestlands in Gera and a nearby district, Shabe-Sombo [76]. The PFM scheme has covered nearly all villages in Gera and used three complimentary strategies: set up local forest management associations, program for forest coffee certification and farmers field schools to simultaneously improve both forest conservation and local livelihoods [76]. Since late 1990s, on the other hand, a total of 1528 ha of the medium-scale forestland in Gera district was transferred to six private companies to engage in shade coffee production (Figure 1, Table 1). The forestland transferred to investors for coffee cultivation after 2007 was part of the lands where the PFM scheme was being established. In October 2013, only four companies, i.e., Abana Coffee Private Limited 
Company (Plc), Ayetu Agricultural and Trading Plc, Trackon Trading's Gera Coffee Development Project and Yukro Agro-Industry Plc's Gera Organic Coffee Project (hereafter Abana, Ayetu, Trackon and Yukro, respectively), were active in the area. This paper focuses mainly on these four companies. The companies were offered forestland at lease rates of 100-150 Ethiopian Birr (ETB; ETB 19.6 = USD 1 on 7 July 2014) per ha per year for 25-40 years (Table 1 ). The companies were expected to create job opportunities, transfer technology (e.g., improved coffee production techniques) to local communities and enhance Ethiopia's foreign currency earnings. Except in the case of Abana, the owners of these companies are domestic investors or diaspora Ethiopians.

Table 1. Year of license, area of investment land, lease period and prior land use types for the land transferred to the private companies in the Gera district of Ethiopia ${ }^{1}$.

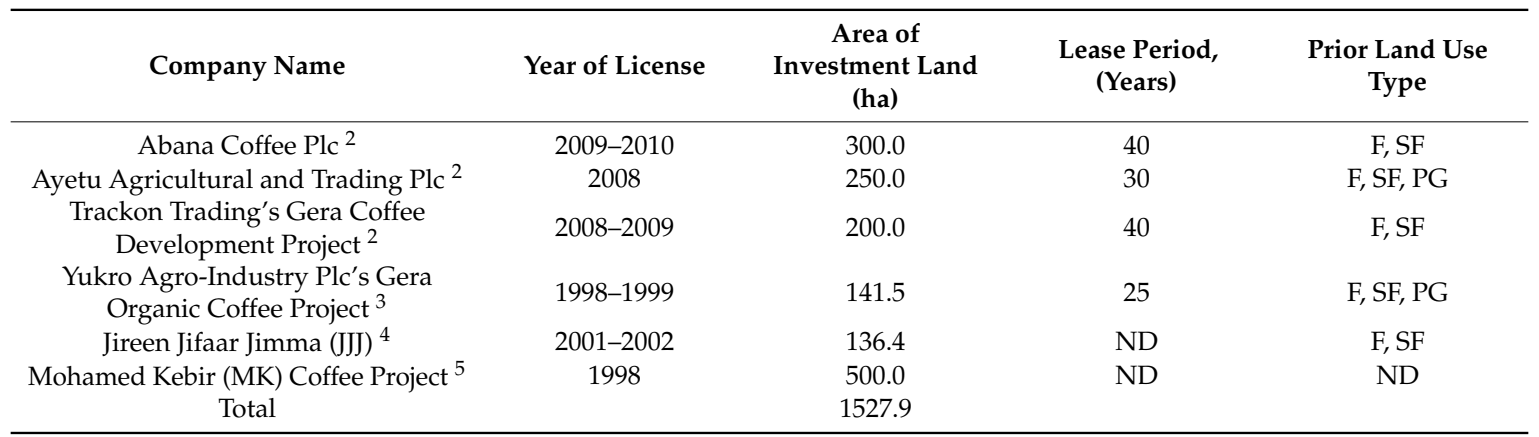

${ }^{1}$ Data compiled from interviews with company representatives, OFWE-JBO staff, farmers and revenue department staff at Gera district administration. ${ }^{2}$ They were expecting the first coffee harvest at the end of 2013. ${ }^{3}$ Unable to enter the international market to generate foreign currency. ${ }^{4}$ Inactive in October 2013 as the owner had died and the company was also held by a bank for loan default. ${ }^{5}$ Bankrupt and closed. ND: no data. F: forestland without or with only a few wild coffee trees that may also contain beehives hung by local farmers. SF: semi-managed forest coffee land. PG: previous home gardens.

\subsection{Data Collection and Analysis}

Data for the study were collected in 2011 (3 May-10 July) and 2013 (4 October-4 November) through interviews, discussions and document (payrolls and letters) review (for more information on villages and participating farmers selection and data collection in 2011 and 2013 see Ango, 2016 [75]). In 2011, eight focus group discussions were conducted in four villages, one with men (25-75 years old, average eight participants) and one with women (35-90 years old, average six participants) in each village, to identify the benefits and challenges of living and farming near the forest. Two of these villages are located near the forest margins in Muje and Sadi Loya kebeles (kebele is the lowest administrative unit) while the other two are located 2-3 km from the forest in Muje and Wanja Kersa (Figure 1). Sadi Loya and Wanja Kersa are located in the coffee-growing zone (1500-2100 masl) and Muje is situated above the coffee-growing zone ( $>2100$ masl). This village sampling design was intended to capture differences in forest-based livelihoods and in perceptions of forest benefits and forest conservation between farmers living at different distances from the forest. The semi-managed forest coffee lands of five of the focus group participants, i.e., three men and two women, had been seized by the state and transferred to the private companies.

During the 2011 and 2013 fieldwork periods, a total of 13 key informants from various kebeles, i.e., Ganji Challa, Kacho Andaracha, Muje, Sadi Loya and Wanja Kersa, were identified through snowball sampling and were interviewed (Figure 1). Six of these informants, four from villages near the forest and two from villages away from the forest, were farmers who were dispossessed by the state of their semi-managed forest coffee land or forestland due to the land transfer to private companies. The others were farmers locally recognized as knowledgeable about access rights to forest, forest benefits and management and the overall effects of the current transfer of forestland to coffee companies on local livelihoods and forest conservation. 
During the 2013 fieldwork period, data were collected from 30 strategically selected farmers living in two areas, one located near the forest in Wanja Kersa (14 informants) and another away from the forest in Dusta above the coffee-growing zone (16 informants). This village sampling design was intended to capture differences in forest-based livelihoods and in perceptions of forest benefits and forest conservation between farmers living at different distances from the forest in landscapes not studied during the previous fieldwork. The interviewed farmers were selected purposively from different ages (range 20-100 years) and genders (13\% women) in order to capture data on varied experiences and perceptions. The interviewed farmers had not been dispossessed of the forest or semi-managed forest coffee lands they were using by the state due to the land transfer to private companies, since both areas selected for these interviews are located far from the places affected by the forestland grabbing. Questions were asked about the benefits obtained from the nearby forest and forest coffee ecosystems, changes in the amount or character of these benefits and in the factors underlying such changes, rights and obstacles in accessing forest resources and forest management practices.

In addition, during the 2013 fieldwork period, representatives of various government offices at the district and regional administration levels as well as OFWE-JBO staff were interviewed about the appropriation of forestland for coffee cultivation, the private companies involved and their relations with local people and the effects of the land appropriation and investment in coffee production on local livelihoods and forest protection. Representatives of Abana, Ayetu, Trackon and Yukro were also interviewed about their coffee production activities and their relations with local people. The numbers of employees of Abana and Trackon were determined by reviewing their payrolls. Letters written by, for example, OFWE-JBO and the Ethiopian Institution of the Ombudsman-Oromia Branch Office about the conflict between farmers and companies were also obtained and reviewed.

The qualitative data gathered during the 2011 and 2013 fieldwork periods were combined and coded to identify emerging themes that were used as analytical categories [77]. The analytical categories were access rights to forest, extent of forest-based livelihoods and the positive and negative impacts of forestland transfers to private companies for coffee production on local farmers' livelihoods and on forest conservation. To safeguard the anonymity of the interviewed farmers, no reference is made to their names or other potentially identifying details (e.g., family size) in the quotations used and results presented.

\section{Results}

\subsection{Access to Forest and Local Forest-Based Livelihoods}

Farmers living in villages both near and away from the forest have gained and/or retained access to the forest through various mechanisms. Historically, customary access rights were established through coffee cultivation and/or placing beehives for honey production in the forest. Such customary rights are still respected by farmers. Other common mechanisms used by farmers to gain access to forest resources were inheritance/gifts of customary rights from relatives living in the coffee-growing zone, crop sharing locally known as yekuto [78] and informal land purchases. All these mechanisms were important to varying degrees for farmers living in villages far from the forest and/or above the coffee-growing zone.

Through yekuto, farmers with customary rights to forest coffee land and other forestland can invite others, including relatives, to engage in forest coffee and honey production, sharing the yield equally. A farmer with customary rights to forestland may, for example, invite a landless immigrant to thin shade trees, clear undergrowth, make some enrichment plantings and later share the coffee harvest with the landowner. Instances of semi-managed forest coffee lands newly carved out of the forest through yekuto being shared equally between the rightful "owner" and "cultivator" after engaging in yekuto for seven to eight years were also reported. Yekuto is also a common way of accessing the forest for honey production. It involves preparing beehives from forest products and tying them to tree branches high up in semi-managed forest coffee and forest (with or without coffee) lands [79]. 
Up to October 2013, some farmers had also received certificates of ownership of semi-managed forest coffee lands from the state, whereas the PFM scheme formalized the informal access rights of its members to the forest for non-timber forest products (NTFPs) after 2003.

Of the several benefits that farmers in villages both near and away from the forest obtained from the forest and semi-managed forest coffee lands, coffee and honey stand out as not only major benefits but also as important cash income sources (Table 2). The amount of cash income that farmers earned from coffee and honey production ranged from a few hundred to over ten thousand ETB per annum as the following two quotations illustrate:

"Each year I earn ten to fifteen thousand Birr [ETB] from the sale of coffee." (A 46-year-old man living in a village near the forest in the coffee-growing zone)

"I own over 200 beehives hung in trees in the forest, which my son has taken on as yekuto and in a good production year we get six farasula [one farasula $=17 \mathrm{~kg}$ ] of honey. We sell one kilogram of unprocessed honey for 28 to 30 Birr [ETB] ... I also own a similar number of beehives in another area." (A 70-year-old man living in a village far from the forest outside the coffee-growing zone)

Table 2. Benefits the farmers interviewed in 2013 obtained from the forest and forest coffee ecosystems in the Gera district of Ethiopia.

\begin{tabular}{|c|c|c|c|}
\hline \multirow{2}{*}{ List of Forest and Forest Coffee Ecosystems Benefits ${ }^{1}$} & \multicolumn{3}{|c|}{$\begin{array}{l}\% \text { of the Interviewed Farmers Who Obtained the } \\
\text { Benefit }\end{array}$} \\
\hline & $\begin{array}{l}\text { Near Forest } \\
\quad(n=14)\end{array}$ & $\begin{array}{l}\text { Far from Forest } \\
\qquad(n=16)\end{array}$ & Total $(n=30)$ \\
\hline Shade for coffee & 85.7 & 75.0 & 80.0 \\
\hline Lianas (e.g., for house, fence and beehive construction) & 78.6 & 50.0 & 63.3 \\
\hline Trees and flowers for honey production & 57.1 & 62.5 & 60.0 \\
\hline Firewood & 100.0 & 18.8 & 56.7 \\
\hline Access to resources for making farm implements & 64.3 & 50.0 & 56.7 \\
\hline $\begin{array}{l}\text { Wood for house and/or fence construction (e.g., } \\
\text { termite-resistant poles) }\end{array}$ & 85.7 & 12.5 & 46.7 \\
\hline Timber for making furniture for one's own use & 64.3 & 0.0 & 30.0 \\
\hline Grazing for livestock & 42.9 & 0.0 & 20.0 \\
\hline Brings rain and lowers warm temperatures (qabbana) & 28.6 & 0.0 & 13.3 \\
\hline Spices (e.g., Piper capense) & 21.4 & 0.0 & 10.0 \\
\hline Other (e.g., medicines and protecting soil from erosion) & 21.4 & 0.0 & 10.0 \\
\hline
\end{tabular}

1 The list of forest benefits was summarized from interviews held in 2013. Although no farmer self-reported the benefit of producing timber for sale, according to interviews with key informants and OFWE-JBO staff members, timber sale is an important income source for some farmers. Logs reportedly confiscated from farmers were observed being stored at the OFWE-JBO office in the town of Chira.

In addition to coffee and honey, the interviewed farmers emphasized that access to lianas (for construction and for tethering beehives to trees), firewood, materials for farm implements, wood for house and/or fence construction and timber for making furniture are important forest benefits (Table 2, Figure 2a,b). Several important forest benefits, for example, firewood, timber for making furniture and livestock grazing, were exploited by farmers living near the forest (Table 2). Shortage of grazing land is an increasing problem facing farmers in Gera and villages on the forest margins; the possibility of grazing livestock in the nearby forestland eases this problem, especially during the dry season when other grazing lands have little fodder. Some farmers living near the forest also collected spices, mainly Piper capense, from the forest and semi-managed forest coffee lands, in addition to valuing the forests for moderating the local climate and controlling soil erosion (Table 2, Figure 2c). 


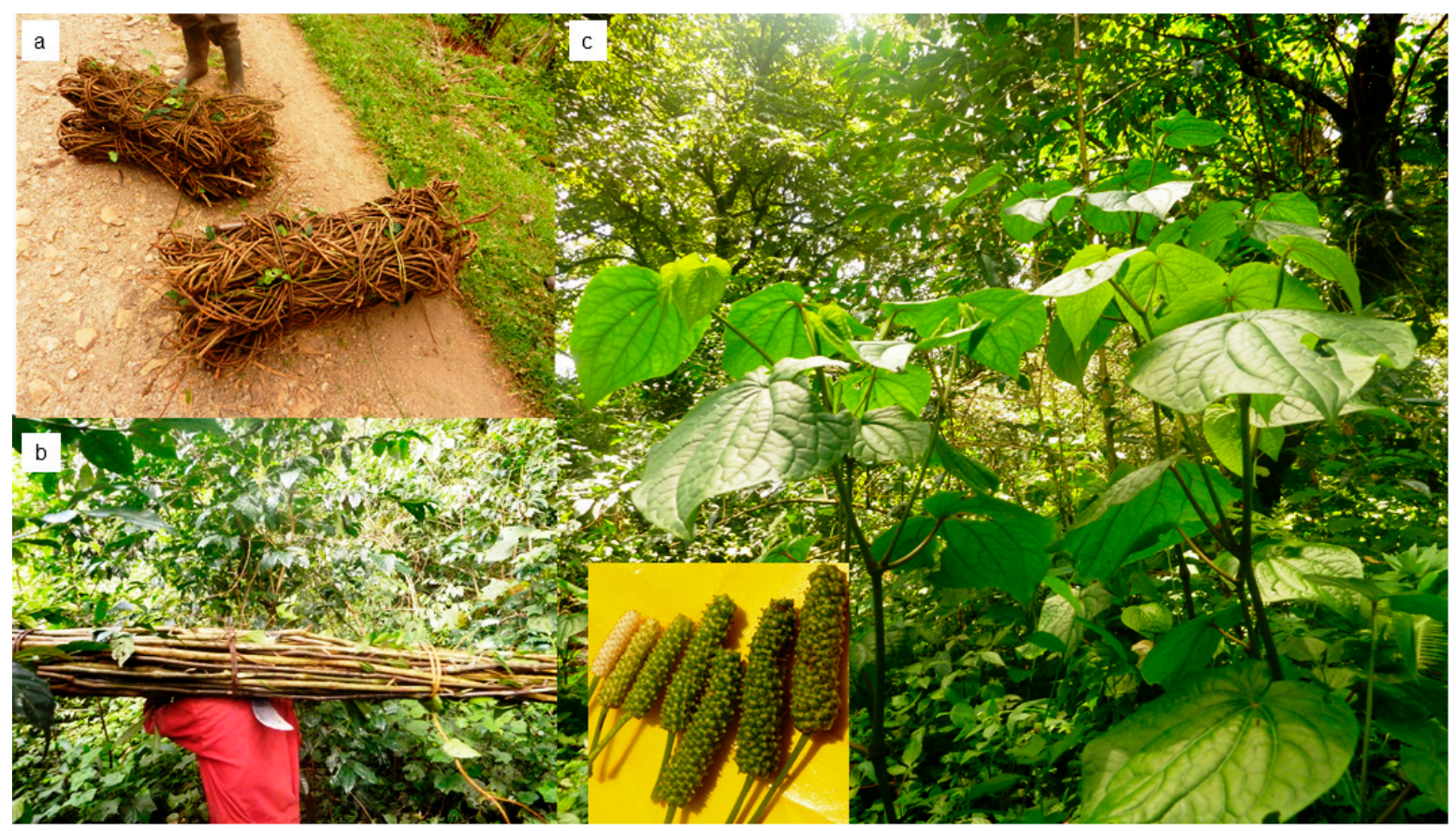

Figure 2. (a) Lianas; (b) young, strong and straight wood for live fences; and (c) Piper capense spice that the farmers collect from forest and forest coffee ecosystems in the Gera district of Ethiopia.

\subsection{Impacts of Forestland Appropriation}

\subsubsection{Conflicts and Livelihood Impacts of Forestland Appropriation}

In 2008, a meeting was organized by the local government in one of the villages where forestland was appropriated in 2008 and after to inform farmers about the coming of investors to engage in coffee production. The main messages conveyed to the local communities at the meeting were that the companies would be given part of the forestland not used by the local community, that the local community would benefit from jobs and technology transfers generated by the investors and that the country would benefit from the production of coffee for export to enhance foreign currency earnings and national development. Apart from that meeting, there was no further consultation with the local community or with the state institution responsible for forest management, i.e., OFWE-JBO, before forestland was appropriated for coffee production. Government body at district level took a leading role in the identification of potential investment land and the Oromia Regional National State and the federal government made the transfers.

Most of the land transferred to the private companies had been used by farmers in Gera for cultivating semi-managed forest coffee, siting beehives for honey production (Table 1) and obtaining other forest products (Table 2). Some parts of the land in Ganji Challa and Sadi Loya, which were transferred to private companies, had been used by a company locally known as "Ethio-Libya" for honey production from c. 1985-1986 to 1991 (senior staff member at Gera agricultural and rural development, 29 October 2013). Interviews have consistently revealed that local farmers had been using the Ethio-Libya land after the company ceased operation in 1991. The land transferred to private companies involved a large portion—in some cases all—of the semi-managed forest coffee land or forestland that farmers could access:

"All my coffee land [i.e., semi-managed forest coffee land] has been given away to Ayetu. Now I have no coffee land ... I am striving to feed ... my ... children by cultivating only cereals.... It took me about five years to thin the shade trees, to plant and manage the 
coffee but now Ayetu took it over." (a 47-year-old affected man living in a village near the forest in the coffee-growing zone)

"The government took the forest where I used to put beehives for honey production ... and offered it to Trackon. The same government that teaches us [i.e., farmers] to conserve forest gave forestland to an investor ... to bulldoze it for coffee cultivation." (a 55-year-old affected man living in a village far from the forest outside the coffee-growing zone)

Over the ten years ending in 2013, groups of 21 and 10 local farmers reported to the district court that Ayetu and Jireen Jifaar Jimma (JJJ), respectively, had appropriated their semi-managed forest coffee lands. Recognizing the appropriation of semi-managed forest coffee land, Ayetu paid compensation to six farmers. Likewise, a group of over 20 farmers reported that Yukro had taken over their semi-managed forest coffee land. Trackon also acknowledged that beehives belonging to local farmers were destroyed when thinning trees and reported that a payment totalling ETB 400 was issued as compensation to two farmers. Abana also reported that about 40 ha of the land granted to them contained coffee trees but that this coffee had "grown naturally." Moreover, Abana reported paying compensation to five farmers who transferred their semi-managed forest coffee land or forestland to the company. However, overall only a total of 13 farmers received compensation for their loss of semi-managed forest coffee land or forestland to the three companies Abana, Ayetu and Trackon. In most cases, the amount of compensation paid was approximately ETB 200-5000 per farmer. Farmers considered this compensation low but they had no other choice than to accept the compensation and leave the land.

In connection with the conflict between the farmers and companies, one adult member of a farming household was killed by gunshot in 2008 when collecting coffee berries from an area under dispute between the household and JJJ. Other conflicts between farmers and companies (i.e., Ayetu, JJJ and Yukro) have led to court cases filed by the farmers and companies, resulting in the imprisonment of several farmers for a few days to up to several weeks and in fines. When following up on court cases, including bringing cases to the Ethiopian Institution of the Ombudsman-Oromia Branch Office, farmers incurred financial costs for transportation and accommodation in towns. They also claimed that the time lost for such efforts resulted in crop raids by wild mammals [78] and the neglect of important farm work, such as ploughing and weeding.

The companies generally did not allow farmers to gather firewood and other NTFPs (e.g., lianas and spices) from their investment areas (Table 3). The only exceptions were Ayetu, which allowed firewood collection every Saturday and Yukro, which allowed firewood collection based on individual requests. The inability to access wood products such as firewood from nearby lands owned by the companies reportedly aggravated firewood shortages, increasing the time required to collect firewood and the burden on women and children, who usually engage in this activity. The coming of the investors aggravated the scarcity of fodder and grazing lands for farmers living in villages near the forest, as the investors prohibited livestock from grazing in their coffee land (Table 3). 
Table 3. Summary of services offered by private companies to farmers, Gera, October 2013.

\begin{tabular}{|c|c|c|c|c|}
\hline \multirow{2}{*}{ List of Services/Benefits } & \multicolumn{4}{|c|}{ Company-Offered Services, Marked 'X' } \\
\hline & Abana & Ayetu & Trackon & Yukro \\
\hline Job opportunities & $x$ & $x$ & $x$ & $x$ \\
\hline $\begin{array}{l}\text { Preparation of specialty coffee seedlings to be distributed to } \\
\text { farmers } 1\end{array}$ & & $x$ & & \\
\hline Allow farmers to collect firewood from company land, every & & $x$ & & $x$ \\
\hline Material support to develop potable water sources 2 & & & $x$ & \\
\hline Constructing two grain mills to serve local people 3 & & & $\mathrm{x}$ & \\
\hline $\begin{array}{l}\text { Borrowed a vehicle to transport an electrical transformer to be } \\
\text { installed to serve the company and some nearby farmers }\end{array}$ & & & $x$ & \\
\hline $\begin{array}{l}\text { Allowed } 60 \text { households to get electricity from its electrical } \\
\text { transformer }\end{array}$ & $x$ & & & \\
\hline $\begin{array}{l}\text { Facilitated the visit of } 15 \text { medical staff from abroad to provide } \\
\text { free eye and dental care to farmers living near the company }\end{array}$ & $x$ & & & \\
\hline $\begin{array}{l}\text { Allow the grazing of livestock on land not yet planted with } \\
\text { coffee by the company }\end{array}$ & & & & $x$ \\
\hline
\end{tabular}

The district administration in Gera viewed the conflicts between the farmers and private companies as stemming from: (i) farmers' insistence that the forestland was their property although it formally belongs to the state; (ii) some farmers' fear that coffee cultivation by the companies, on top of state's forest ownership, would lead to their descendants' being practically cut off from the forest and unable to expand their own cultivation of forest coffee; and (iii) a few trouble-making individuals, who did not even have land in the conflict area, starting and promoting conflicts between local people and the investors; these individuals were said to have a "political problem" (i.e., an agenda to destabilize the government in power and attack its policies). For the district administration, farmers' complaints, appeals and re-appeals to gain the return of parts of the forest land transferred to the companies were just a waste of their time and resources and could not be successful. As the companies had already obtained bank loans using their coffee land as collateral, it is practically impossible to evict them from the land transferred to them.

\subsubsection{Employment Opportunities and Other Services Offered by the Private Companies}

The companies have generated job opportunities and supported certain local development initiatives (Table 3). However, only a few interviewed farmers, mostly from poor and landless families, reported that daily labour for the companies was an important source of cash income. Farmers instead stated that daily labour for the companies was exploitative due to the low wages paid and lack of job security. The daily payment by most companies ranged between ETB 15 and ETB 25 for work in the coffee nurseries and in plot clearing, respectively. All companies also deducted income taxes from the daily wages. Mainly because of the low wages, many farmers were reluctant to work for the companies and instead prioritized working on their own land, meaning that some companies faced labour shortages. The wages paid by the companies compared unfavourably with what farmers would typically earn if they worked on other farmers' land, because in local labour arrangements wages are often paid in kind, for example, $20 \%$ or more (by weight) of the coffee yield collected/harvested. To secure enough labour, Trackon was bringing labourers from distant places such as Konta and Yem. The company also used students to transplant seedlings, as schools were closed during the transplanting season. Abana reported that it could potentially hire up to 400 daily labourers even during slack periods but in 2013, only an estimated 263 and 172 workers were actually hired during the peak and slack periods, respectively.

The farmers considered the job opportunities and various services provided by the coffee-producing companies to the local communities (Table 3) to be far from sufficient compensation 
for the loss of access to semi-managed forest coffee land and forestland. Many farmers stated that the companies were just exploiting farmers' labour by paying such low wages, while taking over the local forest resources as well. The private companies and the district administration, on the other hand, claimed that the job opportunities and other services they offered helped improve local livelihoods. In relation to this, the district administration reported that:

"The companies have already created job opportunities, made technology transfers, constructed flour mills and potable water wells and facilitated and brought eye doctors and dentists from abroad that helped people gain relief from bad teeth and regain sight after many years of blindness. The doctors and dentists donated the medical equipment they brought with them to a health centre at Chira." (Gera district administrator, 28 October 2013)

Moreover, two companies reported that a few farmers in the area did intensify their coffee production after observing their coffee-production activities, which the companies felt would improve the income of these farmers. However, the interviewed farmers did not report gaining any new useful shade coffee production skills or knowledge from the companies. Likewise, the coffee production by the companies has yet to contribute to Ethiopia's foreign currency earnings. One of the companies that had started investing in coffee production in the late 1990s has failed to export coffee, while two other companies had gone bankrupt and closed or were inactive (Table 1). The three remaining companies, which started to invest in coffee production after 2007, had not yet harvested or marketed coffee until November 2013.

\subsubsection{Implications for Forest Biodiversity Conservation}

Neither OFWE-JBO nor its predecessor Jimma Forest Enterprise- a state-owned institution responsible for forest management- was consulted by the district, regional, or federal administrations about the possible negative social-ecological effects of forestland appropriation for coffee production. The private companies, for example, Trackon, had cleared substantial forest areas to establish coffee plantations (Figure 3a). In 2010-2011, OFWE-JBO advised Trackon to stop tree clearing, although this appeal turned out to be unsuccessful. Later, Trackon denied OFWE-JBO access to its coffee development area. In the meantime, the forest clearing case was reported to the regional and federal governments and a politician was sent by the regional government to visit Trackon and evaluate the situation; however, this regional government visit did not make Trackon stop tree clearing at the time.

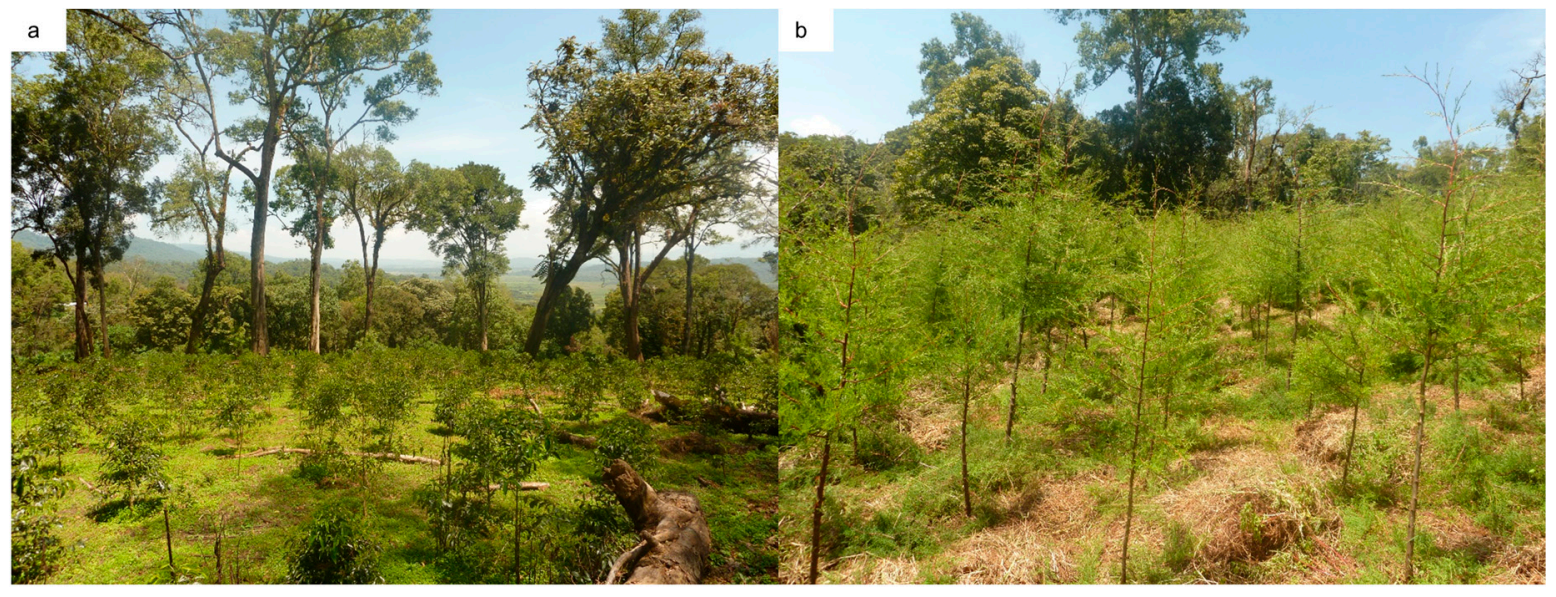

Figure 3. (a) Coffee plantation; and (b) newly established Cupressus lusitanica plantation in Trackon's coffee investment land in October 2013, Gera district, Ethiopia.

According to the district administration, Trackon had initially cleared some forest-a "mistake" that the company has not repeated. Trackon itself reported that it did not engage in deforestation and 
claimed that the belief that it had cleared forest was a misconception arising from poor communication and lack of close interaction with the local community in previous years. Trackon claimed that it had only done some heavy thinning of trees in certain parts of its coffee land. However, a visit to Trackon's coffee farm in October 2013 revealed that only a few shade trees remained and that undergrowth was non-existent in most parts of the visited coffee fields (Figure 3a). Many big trees that had been left as shade trees had fallen due to exposure to winds and to root disturbance from cultivation. From the interviews and observation, it was clear that Trackon had used bulldozers to clear the forest on at least some parts of its land, both for coffee cultivation and to build access roads. Trackon constructed a 22-km-long road about four meters wide, while Abana constructed about $12 \mathrm{~km}$ of road on its land.

The companies have thinned the shade trees much more intensively than the farmers previously did on the same land. In addition to thinning shade trees and removing undergrowth, the coffee companies had also undertaken other activities with negative implications for biodiversity; for example, some companies planted exotic trees such as Grevillea robusta and Cupressus lusitanica in windbreaks and plantations. Until November 2013, Trackon, for example, had planted 10,000 Cupressus lusitanica and 4500 Grevillea robusta seedlings, mostly as plantations on land from which forest was removed (Figure 3b). Trackon and Yukro also sprayed herbicides to suppress undergrowth and to change the flora to herbaceous or "soft weeds."

In addition, the establishment of the private companies' coffee farms in Gera created incentives for local communities to convert forestland to mainly semi-managed forest coffee land in an endeavour to improve the security of their customary rights to the land. In connection to this, a letter from OFWE-JBO to the OFWE head office, dated 1 June 2011, about forestland transferred to private companies for coffee investment in Gera and nearby districts, emphasized the local resentment and related forestland conversions:

"Because of the transfer of forestland to investors, communities living along the forest margins have started a campaign of planting coffee seedlings in the adjacent forest [ ... ] and of converting the land to agriculture [ ... ] with the intention to claim ownership of the forest, which they think that they have been conserving and living with for a long time, before it is transferred to investors for coffee investment." (translated from Afaan Oromo)

\section{Discussion}

\subsection{Livelihood Impacts of Forestland Appropriation}

The present analysis has shown that medium-scale forestland appropriation for coffee production by private companies has led to the loss of access to key resources needed for local farmer sustenance. This forestland appropriation has created in situ displacement, preventing farmers from accessing forest resources, not only to produce coffee and honey but also to obtain other products that supplement their livelihoods (Table 3). This effective alienation of farmers from forestland transferred to private companies marks an end to state control of the forest-a control that the state had exercised with conservation as the main justification [56] - to which local communities had managed to maintain informal access and from which they had successfully earned forest-based livelihoods [59,60].

The findings that forestland appropriation by the companies took away an important part of the farmers' livelihood with little or no compensation and that the conflict between the companies and farmers imposed financial and opportunity costs on farmers when they pursued court action, illustrate how medium-scale forestland appropriations can undermine the affected farmers' livelihoods and food security. Such medium-scale land appropriations should not be considered minor in impact relative to that of current large- and mega-scale land grabbing in Ethiopia and elsewhere $[3,14,80,81]$, as they have relatively large-scale aggregate consequences despite the relatively "small" individual areas appropriated $[28,82]$. The local livelihood insecurity and food insecurity resulting from largeand mega-scale land grabbing are mainly consequences of the focus on export crop production on the appropriated land and of the inadequate number and poor pay, of the jobs created by the investments 
on the appropriated lands $[3,11,81,83]$. In the case of forestland appropriation in Gera, although the private companies did create many jobs, many farmers were not interested in taking these poorly paid temporary jobs as a strategy to improve their livelihoods and food security, suggesting that the government's use of job creation for local residents as one of the main justifications for forestland appropriation is largely irrelevant.

In Ethiopia and elsewhere, inadequate compensation for appropriated land is a general problem $[22,23,84]$. The absence of compensation for many of the appropriations in Gera was clearly attributed to the claim that the state owns the forest and that the locals' use of it was therefore illegal $[57,70]$. This makes the transfer of forestlands for coffee production unassailable in the eyes of uncritical observers. Deconstruction of this claim of legality, however, reveals that it is based on earlier appropriations and control of the communal forest by previous regimes over the past approximately 120 years $[55,85,86]$. This history of historical dispossessions and marginalization contributes to making local communities and their informal access to the forest in Gera, easy prey for contemporary appropriations-a widespread problem in relation to common resources in many countries in the global south $[6,7,87]$.

Moreover, the contribution of the private companies in terms of technology transfer to local communities, as often the case also with large- and mega-scale land transactions [22,84], was not evident. Initiatives such as supporting farmers to engage in producing specialty coffee would seem to have promising potential if implemented as planned (Table 3). However, even such initiatives are likely to expose farmers' livelihoods to new risks by establishing new social production relations, as a growing number of studies have already demonstrated in relation to out-grower schemes connected to larger-scale biofuel and sugarcane production in Ethiopia and elsewhere [18,52,53].

The finding that an early-established private company had failed to export coffee, while two other companies had gone bankrupt and closed or remained inactive (Table 1), as is also the case with some companies engaging in large- and mega-scale agricultural investments $[3,88]$, suggests that the potential contribution of these private companies to national foreign currency earnings is relatively meagre. The underperformance of the earlier established companies was unexpected given the possibility of earning more profits from exporting than from selling coffee domestically [89], the low wages and cheap land leases [26], the assumed entrepreneurial skills usually associated with investors and the engagement in producing coffee, a crop with an established international market. The companies' inability to be profitable seems to relate to lack of capacity (e.g., coffee marketing) and conflicts over the transferred land, two among several other major determinants that also caused many companies engaged in large commercial farms to fail to use all the land area transferred to them $[11,90]$. Conflicts over the transferred forestland were observed to at least delay the activities (e.g., project start) of some of the companies in Gera. Such delays occurred even though the companies, like those engaged in large- and mega-scale land investments, had been receiving full support from the government at all administrative levels, including mitigating and/or suppressing conflicts over the appropriated forestland between the investors and farmers in favour of the investors [3,7,91]. Overall, although the expected outcomes have clearly not been achieved, it is too early to make a conclusive statement about the contribution that the recently established companies could make by transferring technology to farmers and enhancing foreign currency earnings.

\subsection{Implications for Forest Biodiversity Conservation}

The private companies' importation of labour to the area, to compensate for the inadequate local labour supply, is clearly reminiscent of earlier periods' labour importation from other parts of the country to the southwest, which then resulted in increased deforestation [63]. How long the current migrant labourers will continue to work for the companies is an open question. Historically, migrant labourers, for example, on the state coffee farms in a neighbouring district, eventually settled in the area on land they obtained through informal arrangements [63]. As demonstrated here, such informal arrangements are still practiced in Gera. The arrival of migrant labourers who may well settle 
as farmers could put added pressure on the remaining forest, which was already facing increased conversions to coffee plantations by the companies and from local farmers' efforts to secure rights to forestland by more intensive use.

As noted here, the forestland transferred to the companies after 2007 was part of the land to be included in the PFM scheme, initiated in 2003, that had acknowledged farmers' customary use rights to NTFPs by incorporating the informal right holders as members of forest management associations. Up to 2012 with JICA support, the PFM scheme showed promising results in terms of improving member farmers' incomes [92] and reducing deforestation [66]. However, the transfer of forestland to the companies was a source of resentment for farmers who had lost their forestland; in addition, it created a sense of insecurity in other PFM member farmers that negatively affected the performance of PFM and forest conservation [76].

On the other hand, the fact that farmers living away from the forest, like those on the forest margins, have managed to maintain access to the forest and obtained many vital benefits from it (Table 2) indicates the importance of the forest ecosystem services in their livelihoods. The diverse benefits-ranging from coffee cultivation, honey production and livestock grazing to firewood, wood for construction and farm implements and climate moderation - that the farmers obtain from the forest further illustrate the extent of the link between the local farmers and forest. This link between forest and local farmers is more likely an important entry point or opportunity to promote local development and forest conservation synergy; for example, the production of shade coffee and honey- both of which have national economic significance $[79,93]$ and clearly requires the presence of trees- than is transferring forestland to investors to develop coffee plantations. Furthermore, it is clear that forest coffee ecosystems use and management by local farmers in southwest Ethiopia has effectively reduced deforestation for at least the past forty years [38] and that this land use is better from the perspective of biodiversity conservation than is conversion to crop cultivation, including coffee plantations [37,94]. Increasing intensification of coffee production, as in coffee plantations by some companies, in the forest coffee ecosystem is also likely to have a detrimental effect on the genetic pool of coffee, which serves as insurance against pests, diseases and climate change [95]. Equally important, the land use associated with forest coffee ecosystem use and management by local farmers is well in line with Ethiopia's current development strategy for a climate-resilient inclusive green economy, which envisages the conservation and rehabilitation of forests to ensure their ecosystem services as one of its main pillars [8].

\section{Conclusion and Way Forward}

This study demonstrated how the medium-scale forestland appropriations have created in situ displacement and become detrimental to local livelihoods and forest conservation in a way that recalls criticisms of the large- and mega-scale international land grabs in the peripheral lowlands of Ethiopia and elsewhere in the global south over the past ten years (e.g., $[3,5,7,10,12,19])$. Local farmers' low interest in taking up the alternative livelihood option (i.e., low-paying temporary jobs), the absence of technology transfers from the companies to the farmers and the inability of earlier established companies to contribute to Ethiopia's foreign currency earnings through coffee exports coupled with the aggravated deforestation from the local farmers' efforts to secure access through more intensive use following the forestland transfers to private companies highlight the overall failure to achieve the objectives of transferring forestland to private companies. Hence, the government's strategy of transferring forestland to private companies was clearly ill-informed and indeed turned out to be counterproductive not only from a local livelihood and food security but also from a conservation perspective. There is a critical need for the government to shift institutional supports to, for example, informal forest access (cf., [96]) and shade coffee production and marketing by local farmers (cf., [97]), for better development and conservation outcomes.

In the meantime, mitigation of conflicts between already established private companies and the farmers require local and regional governments' serious consideration of silenced voices of the 
affected farmers and attempt to fairly address their claims. Improving wage rates and job security at the companies might make the job opportunities created by the companies attractive to many local people- in particular to poor and landless families- and contribute to local food security. Evaluating companies' production and export performance at certain time interval could improve companies' performances while such evaluation serves also as basis for the government interventions including takeover of the forestlands of companies constantly underperforming. Although this study illustrates empirical evidence to support the negative effects of forestland appropriation for coffee production by private companies on forest biodiversity, these effects were not quantified, for example, in terms of the level of tree species diversity maintained in the farms. Further study is required to measure the status of overall biodiversity in the private companies' coffee farms to generate better understanding that informs formulation of stringent strategies that set and maintain minimum standard of biodiversity in these farms.

Acknowledgments: This work was funded by grants from the Swedish International Development Cooperation Agency (Sida, contract number: SWE-2009-134) and the Swedish Research Council Formas (contract number: 229-2009-991) to Kristoffer Hylander. The author gratefully acknowledges Lowe Börjeson, Feyera Senbeta, Peter Kinlund, Jens Friis Lund and Mats Widgren for reviewing earlier versions of this manuscript and making suggestions for improvements. The author would also like to thank field assistants and other individuals for their support during the fieldwork and all the interviewed farmers for their time spent sharing their life experiences; and the anonymous reviewers for their insightful comments.

Conflicts of Interest: The author declares that there is no conflict of interests.

\section{References}

1. Kaimowitz, D.; Sheil, D. Conserving what and for whom? Why conservation should help meet basic human needs in the tropics. Biotropica 2007, 39, 567-574. [CrossRef]

2. FAO, Food and Agriculture Organization of the United Nations. State of the World's Forests: Enhnacing the Scocioeconomic Benefits from Forests; FAO: Rome, Italy, 2014; ISBN 9789251082690.

3. Rahmato, D. The perils of development from above: Land deals in Ethiopia. Afr. Ident. 2014, 12, $26-44$. [CrossRef]

4. Baumgartner, P. Change in trend and new types of large-scale investments in Ethiopia. In Handbook of Land and Water Grabs in Africa: Foreign Direct Investment and Food and Water Security; Allan, T., Keulertz, M., Sojamo, S., Warner, J., Eds.; Routledge: London, UK, 2012; pp. 176-190, ISBN 9781857436693.

5. Davis, K.F.; Yu, K.; Rulli, M.C.; Pichdara, L.; D'Odorico, P. Accelerated deforestation driven by large-scale land acquisitions in Cambodia. Nat. Geosci. 2015, 8, 772-775. [CrossRef]

6. Wily, L.A. "The law is to blame": The vulnerable status of customary land rights in Africa. Dev. Chang. 2011, 42, 733-757. [CrossRef]

7. Dell'Angelo, J.; D'Odorico, P.; Rulli, M.C.; Marchand, P. The tragedy of the grabbed commons: Coercion and dispossession in the global land rush. World Dev. 2017, 92, 1-12. [CrossRef]

8. FDRE, Federal Democratic Republic of Ethiopia. Ethiopia's Climate-Resilient Green Economy: Green Economy Strategy; FDRE: Addis Ababa, Ethiopia, 2011.

9. Cotula, L.; Vermeulen, S.; Leonard, R.; Keeley, J. Land Grab or Development Opportunity? Agricultural Investment and International Land Deals in Africa; IIED/FAO/IFAD: London, UK, 2009; ISBN 9781843697411.

10. De Schutter, O. How not to think of land-grabbing: Three critiques of large-scale investments in farmland. J. Peasant Stud. 2011, 38, 249-279. [CrossRef]

11. Ali, D.A.; Deininger, K.; Harris, A. Using national statistics to increase transparency of large land acquisition: Evidence from Ethiopia. World Dev. 2017, 93, 62-74. [CrossRef]

12. The Many Faces of Land Grabbing: Cases from Africa and Latin America. Available online: https://www.grain.org/article/entries/4908-ejolt-report-10-the-many-faces-of-land-grabbingcases-from-africa-and-latin-america (accessed on 14 February 2018).

13. Ince, O.U. Primitive accumulation, new enclosures, and global land grabs: A theoretical intervention. Rural Sociol. 2014, 79, 104-131. [CrossRef]

14. Shete, M.; Rutten, M. Impacts of large-scale farming on local communities' food security and income levels-Empirical evidence from Oromia region, Ethiopia. Land Use Policy 2015, 47, 282-292. [CrossRef] 
15. Zoomers, A. Globalisation and the foreignisation of space: Seven processes driving the current global land grab. J. Peasant Stud. 2010, 37, 429-447. [CrossRef]

16. Baumgartner, P.; von Braun, J.; Abebaw, D.; Müller, M. Impacts of large-scale land investments on income, prices, and employment: Empirical analyses in Ethiopia. World Dev. 2015, 72, 175-190. [CrossRef]

17. Lavers, T. "Land grab" as development strategy? The political economy of agricultural investment in Ethiopia. J. Peasant Stud. 2012, 39, 105-132. [CrossRef]

18. Lavers, T. Patterns of agrarian transformation in Ethiopia: State-mediated commercialisation and the "land grab". J. Peasant Stud. 2012, 39, 795-822. [CrossRef]

19. Moreda, T. Large-scale land acquisitions, state authority and indigenous local communities: Insights from Ethiopia. Third World Q. 2017, 38, 698-716. [CrossRef]

20. Timko, J.A.; Amsalu, A.; Acheampong, E.; Teferi, M.K. Local perceptions about the effects of Jatropha (Jatropha curcas) and castor (Ricinus communis) plantations on households in ghana and ethiopia. Sustainability 2014, 6, 7224-7241. [CrossRef]

21. Schoneveld, G.C. The geographic and sectoral patterns of large-scale farmland investments in sub-Saharan Africa. Food Policy 2014, 48, 34-50. [CrossRef]

22. Rahmato, D. Land to Investors: Large-Scale Land Transfers in Ethiopia; Forum for Social Sciences: Addis Ababa, Ethiopia, 2011; ISBN 9994450409.

23. Makki, F. Power and property: Commercialization, enclosures, and the transformation of agrarian relations in Ethiopia. J. Peasant Stud. 2012, 39, 81-104. [CrossRef]

24. Makki, F. Development by dispossession: Terra nullius and the social-ecology of new enclosures in Ethiopia. Rural Sociol. 2014, 79, 79-103. [CrossRef]

25. Dadi, D.; Stellmacher, T.; Azadi, H.; Abebe, K.; Senbeta, F. The impact of industrialization on land use and livelihoods in Ethiopia: Agricultural land conversion around Gelan and Dukem town, Oromia region. In Socio-Ecological Change in Rural Ethiopia: Understanding Local Dynamics in Environmental Planning and Natural Resource Management; Stellmacher, T., Ed.; Peter Lang AG: Frankfurt, Germany, 2015; pp. 37-59.

26. El Ouaamari, S.; Cochet, H. The role of coffee in the development of southwest Ethiopia's forests: Farmers' strategies, investor speculation, and certification projects. Soc. Nat. Resour. An Int. J. 2014, 27, 200-214. [CrossRef]

27. Kandel, M. Politics from below? Small-, mid- and large-scale land dispossession in Teso, Uganda, and the relevance of scale. J. Peasant Stud. 2015, 42, 635-652. [CrossRef]

28. Friis, C.; Nielsen, J.Ø. Small-scale land acquisitions, large-scale implications: Exploring the case of Chinese banana investments in northern Laos. Land Use Policy 2016, 57, 117-129. [CrossRef]

29. CSA, Central Statistical Agency. Population Projection of Ethiopia for All Regions at Wereda Level from 2014-2017; CSA: Addis Ababa, Ethiopia, 2013.

30. FAO, Food and Agricultural Organization of the United Nations. Ethiopian Highlands Reclamation Study, Final Report; FAO: Rome, Italy, 1986; Volume 1.

31. Senbeta, F. Biodiversity and Ecology of Afromontane Rainforest with Wild Coffea arabica L. Populations in Ethiopia; University of Bonn: Bonn, Germany, 2006.

32. Belay, H.; Urgessa, K.; Lemenih, M.; Kebebew, Z. Forest dependency among forest user communities in and around Belete-Gera forest, southwest Ethiopia. Int. J. Ecol. Dev. 2013, 26, 50-60.

33. Ango, T.G.; Börjeson, L.; Senbeta, F.; Hylander, K. Balancing ecosystem services and disservices: Smallholder farmers' use and management of forest and trees in an agricultural landscape in southwestern Ethiopia. Ecol. Soc. 2014, 19, 30. [CrossRef]

34. FDRE, Federal Democratic Republic of Ethiopia. Coffee Opportunities in Ethiopia. Presentation of the Ministry of Trade. Available online: www.eafca.org/wwc/downloads/AFCCE09/presentations/Coffee (accessed on 19 November 2015).

35. Gole, T.W. Coffee: Ethiopia's Gift to the World the Traditional Production; Environment and Coffee Forest Forum: Addis Ababa, Ethiopia, 2015.

36. Kufa, T. Recent coffee research development in Ethiopia. Presented at Ethiopian Coffee Export Conference: Strengthening the Legacy of Our Coffee, Hilton, Addis Ababa, Ethiopia, 8-9 November 2012.

37. Tadesse, G.; Zavaleta, E.; Shennan, C. Coffee landscapes as refugia for native woody biodiversity as forest loss continues in southwest Ethiopia. Biol. Conserv. 2014, 169, 384-391. [CrossRef] 
38. Hylander, K.; Nemomissa, S.; Delrue, J.; Enkosa, W. Effects of coffee management on deforestation rates and forest integrity. Conserv. Biol. 2013, 27, 1031-1040. [CrossRef] [PubMed]

39. FDRE, Federal Democratic Republic of Ethiopia. Growth and Transformation Plan; FDRE: Addis Ababa, 2010.

40. Wily, L.A. Looking back to see forward: The legal niceties of land theft in land rushes. J. Peasant Stud. 2012, 39, 751-775. [CrossRef]

41. Edelman, M.; Oya, C.; Borras, S.M. Global Land Grabs: Historical processes, theoretical and methodological implications and current trajectories. Third World Q. 2013, 34, 1517-1531. [CrossRef]

42. Fairhead, J.; Leach, M.; Scoones, I. Green Grabbing: A new appropriation of nature? J. Peasant Stud. 2012, 39, 237-261. [CrossRef]

43. German, L.; Mandondo, A.; Paumgarten, F.; Mwitwa, J. Shifting rights, property and authority in the forest frontier: "Stakes" for local land users and citizens. J. Peasant Stud. 2014, 41, 51-78. [CrossRef]

44. Tura, H.A. Land rights and land grabbing in Oromia, Ethiopia. Land Use Policy 2018, 70, 247-255. [CrossRef]

45. Harvey, D. The New Imperialism; Oxford University Press: Oxford, UK, 2003; ISBN 0199264317.

46. Marx, K. Capital; Electric Book Comapnay: London, UK, 2000; Volume I.

47. Rahmato, D. The Peasant and the State: Studies in Agrarian Change in Ethiopia 1950s-2000s; Addis Ababa University Press: Addis Ababa, Ethiopia, 2009.

48. Benjaminsen, T.A.; Bryceson, I. Conservation, green/blue grabbing and accumulation by dispossession in Tanzania. J. Peasant Stud. 2012, 39, 335-355. [CrossRef]

49. Levien, M. From primitive accumulation to regimes of dispossession: Six theses on India's land question. Econ. Political Wkly. 2015, 50, 146-157.

50. Feldman, S.; Geisler, C.; Silberling, L. Moving targets: Displacement, impoverishment, and development. Int. Soc. Sci. J. 2003, 55, 7-13. [CrossRef]

51. Feldman, S.; Geisler, C. Land expropriation and displacement in Bangladesh. J. Peasant Stud. 2012, 39, 971-993. [CrossRef]

52. Wendimu, M.A.; Henningsen, A.; Gibbon, P. Sugarcane outgrowers in Ethiopia: "Forced" to remain poor? World Dev. 2016, 83, 84-97. [CrossRef]

53. Hall, R. Land grabbing in Southern Africa: The many faces of the investor rush. Rev. Afr. Political Econ. 2011, 38, 193-214. [CrossRef]

54. Markakis, J. Ethiopia: The Last Two Frontiers; James Currey: London, UK, 2011.

55. Zewdie, Y. Access to Forest Resources and Forest-Based Livelihoods in Highland Kafa, Ethiopia: A Resource Management Perspective; University of Huddersfield: Huddersfield, UK, 2002.

56. Bekele, M. Forest Property Rights, the Role of the State and Institutional Exigency; Swedish University of Agricultural Sciences: Umea, Sweden, 2003.

57. FDRE, Federal Democratic Republic of Ethiopia. Constitution of the Federal Democratic Republic of Ethiopia; FDRE: Addis Ababa, 1995.

58. Ribot, J.C.; Peluso, N.L. A theory of access. Rural Sociol. 2003, 68, 153-181. [CrossRef]

59. Stellmacher, T. The historical development of local forest governance in Ethiopia-From imperial times to the military regime of the Derg. Afr. Spectr. 2007, 42, 519-530.

60. Wakjira, D.T.; Fischer, A.; Pinard, M.A. Governance change and institutional adaptation: A case study from Harenna forest, Ethiopia. Environ. Manag. 2013, 51, 912-925. [CrossRef] [PubMed]

61. Chilalo, M.; Wiersum, K.F. The role of non-timber forest products for livelihood diversification in Southwest Ethiopia. Ethiop. E J. Res. Innov. Foresight 2011, 3, 44-59.

62. Ayana, A.N.; Arts, B.; Wiersum, K.F. Historical development of forest policy in Ethiopia: Trends of institutionalization and deinstitutionalization. Land Use Policy 2013, 32, 186-196. [CrossRef]

63. Matsumura, K. Changes beyond the State institution: Socialist policies and land tenure in a coffee-growing village, southwestern Ethiopia. Nilo-Ethiop. Stud. 2003, 8-9, 13-34. [CrossRef]

64. Sylvain, P.G. Ethiopian coffee: Its significance to world coffee problems. Econ. Bot. 1958, 12, 111-139. [CrossRef]

65. Gole, T.W.; Denich, M.; Teketay, D.; Vlek, P.L.G. Human impacts on the Coffea arabica genepool in Ethiopia and the need for its in situ conservation. In Managing Plant Genetic Diversity; Engels, J.M.M., Ramanatha Rao, V., Brown, A.H.D., Jackson, M.T., Eds.; CAB International: Wallington, UK, 2002; pp. 237-247.

66. Takahashi, R.; Todo, Y. Impact of community-based forest management on forest protection: Evidence from an aid-funded project in Ethiopia. Environ. Manag. 2012, 50, 396-404. [CrossRef] [PubMed] 
67. Ameha, A.; Larsen, H.O.; Lemenih, M. Participatory forest management in Ethiopia: Learning from pilot projects. Environ. Manag. 2014, 53, 838-854. [CrossRef] [PubMed]

68. Ameha, A.; Nielsen, O.J.; Larsen, H.O. Impacts of access and benefit sharing on livelihoods and forest: Case of participatory forest management in Ethiopia. Ecol. Econ. 2014, 97, 162-171. [CrossRef]

69. Tadesse, S.; Woldetsadik, M.; Senbeta, F. Impacts of participatory forest management on forest conditions: Evidences from Gebradima Forest, southwest Ethiopia. J. Sustain. For. 2016, 35, 604-622. [CrossRef]

70. FDRE, Federal Democratic Republic of Ethiopia. Forest Development, Conservation and Utilization; Proclamation No. 542/2007; FDRE: Addis Ababa, Ethiopia, 2007.

71. Angelsen, A.; Brockhaus, M.; Kanninen, M.; Sills, E.; Sunderlin, W.D.; Wertz-Kanounnikoff, S. (Eds.) Realising REDD+: National Strategy and Policy Options; CIFOR: Bogor, Indonesia, 2009.

72. Bekele, M.; Tesfaye, Y.; Mohammed, Z.; Zewdie, S.; Tebikew, Y.; Brockhaus, M.; Kassa, H. The Context of REDD+ in Ethiopia: Drivers, Agents, and Institutions; Occasional Paper; CIFOR: Bogor, Indonesia, 2015.

73. Oromia Burea of Finance and Economic Development. Jimma Zone Districts' Physical E Socio-Economic Profile; (Unpblished report).

74. CSA, Central Statistical Authority. The 1994 Population and Housing Census of Ethiopia: Statistical Report on Population Size and Characteristics for Oromia Region; CSA: Addis Ababa, Ethiopia, 1996; Part II; Volume I.

75. Ango, T.G. Ecosystem Services and Disservices in an Agriculture-Forest Mosaic: A Study of Forest and Tree Management and Landscape Transformation Southwestern Ethiopia. Ph.D. Thesis, Stockholm University, Stockholm, Sweden, 2016.

76. Lemenih, M.; Negassa, A. A Study of the Process, Progress and Impacts of Belete-Gera Participatory Forest Management Project; Final Report; (Unpublished report).

77. Bryman, A. Social Research Methods, 4th ed.; Oxford University Press: Oxford, UK, 2012.

78. Ango, T.G.; Börjeson, L.; Senbeta, F. Crop raiding by wild mammals in Ethiopia: Impacts on the livelihoods of smallholders in an agriculture-forest mosaic landscape. Oryx 2017, 51, 527-537. [CrossRef]

79. Ito, Y. Local honey production activities and their significance for local people: A case of mountain forest area of southwestern Ethiopia. In African Study Monographs, Suppl. 48; Kyoto University Research Information Repository: Kyoto, Japan, 2014; pp. 77-97.

80. Abbink, J. "Land to the foreigners": Economic, legal, and socio cultural aspects of new land acquisition schemes in Ethiopia. J. Contemp. Afr. Stud. 2011, 29, 513-535. [CrossRef]

81. Davis, K.F.; D'Odorico, P.; Rulli, M.C. Land grabbing: A preliminary quantification of economic impacts on rural livelihoods. Popul. Environ. 2014, 36, 180-192. [CrossRef] [PubMed]

82. Cotula, L. The international political economy of the global land rush: A critical appraisal of trends, scale, geography and drivers. J. Peasant Stud. 2012, 39, 649-680. [CrossRef]

83. Li, T.M. Centering labor in the land grab debate. J. Peasant Stud. 2011, 38, 281-298. [CrossRef]

84. Schoneveld, G.C. Host country governance and the African land rush: 7 reasons why large-scale farmland investments fail to contribute to sustainable development. Geoforum 2017, 83, 119-132. [CrossRef]

85. Turton, D. The Mursi and national park development in the lower Omo valley. In Conservation in Africa: Peoples, Policies and Practice; Anderson, D., Grove, R.H., Eds.; Cambridge University Press: Cambridge, UK, 1988; pp. 168-186.

86. Bulcha, M.B. Contours of the Emergent and Ancient Oromo Nation: Dilemmas in the Ethiopian Politics of State and Nation-Building; Creda Communications: Cape Town, South Africa, 2011; ISBN 9781920287238.

87. German, L.; Schoneveld, G.C.; Mwangi, E. Contemporary processes of large-scale land acquisition in Sub-Saharan Africa: Legal deficiency or elite capture of the rule of law? World Dev. 2013, 48, 1-18. [CrossRef]

88. Gill, B. Can the river speak? Epistemological confrontation in the rise and fall of the land grab in Gambella, Ethiopia. Environ. Plan. A 2015, 48, 699-717. [CrossRef]

89. Shumeta, Z.; Urgessa, K.; Kebebew, Z. Analysis of market chains of forest coffee in southwest Ethiopia. Acad. J. Plant Sci. 2012, 5, 28-39. [CrossRef]

90. Teklemariam, D.; Azadi, H.; Nyssen, J.; Haile, M.; Witlox, F. How sustainable is transnational farmland acquisition in Ethiopia? Lessons learned from the Benishangul-Gumuz Region. Sustainability 2016, 8, 213. [CrossRef]

91. Moreda, T. Listening to their silence? The political reaction of affected communities to large-scale land acquisitions: Insights from Ethiopia. J. Peasant Stud. 2015, 42, 517-539. [CrossRef] 
92. Todo, Y.; Takahashi, R. Impact of farmer field schools on agricultural income and skills: Evidence from an aid-funded project in rural Ethiopia. J. Int. Dev. 2013, 25, 362-381. [CrossRef]

93. Bachewe, F.N.; Berhane, G.; Minten, B.; Taffesse, A.S. Agricultural Growth in Ethiopia (2004-2014): Evidence and Drivers; International Food Policy Research Institute: Washington, DC, USA, 2015.

94. Senbeta, F.; Denich, M. Effects of wild coffee management on species diversity in the Afromontane rainforests of Ethiopia. For. Ecol. Manag. 2006, 232, 68-74. [CrossRef]

95. Aerts, R.; Berecha, G.; Honnay, O. Protecting coffee from intensification. Science 2015, 347, 139. [CrossRef] [PubMed]

96. Cronkleton, P.; Artati, Y.; Baral, H.; Paudyal, K.; Banjane, M.R.; Liu, J.L.; Tu, T.Y.; Putzel, L.; Birhane, E.; Kassa, H. How do property rights reforms provide incentives for forest landscape restoration? Comparing evidence from Nepal, China and Ethiopia. Int. For. Rev. 2017, 19, 8-23.

97. Minten, B.; Dereje, M.; Engida, E.; Kuma, T. Coffee value chains on the move: Evidence in Ethiopia. Food Policy 2017. [CrossRef]

(C) 2018 by the author. Licensee MDPI, Basel, Switzerland. This article is an open access article distributed under the terms and conditions of the Creative Commons Attribution (CC BY) license (http:/ / creativecommons.org/licenses/by/4.0/). 